Historic, Archive Document

Do not assume content reflects current scientific knowledge, policies, or practices. 



\section{Annual Catalogue of Hardy 'Trees, Shrubs and Plants Suitable for the Northwestern Planter}

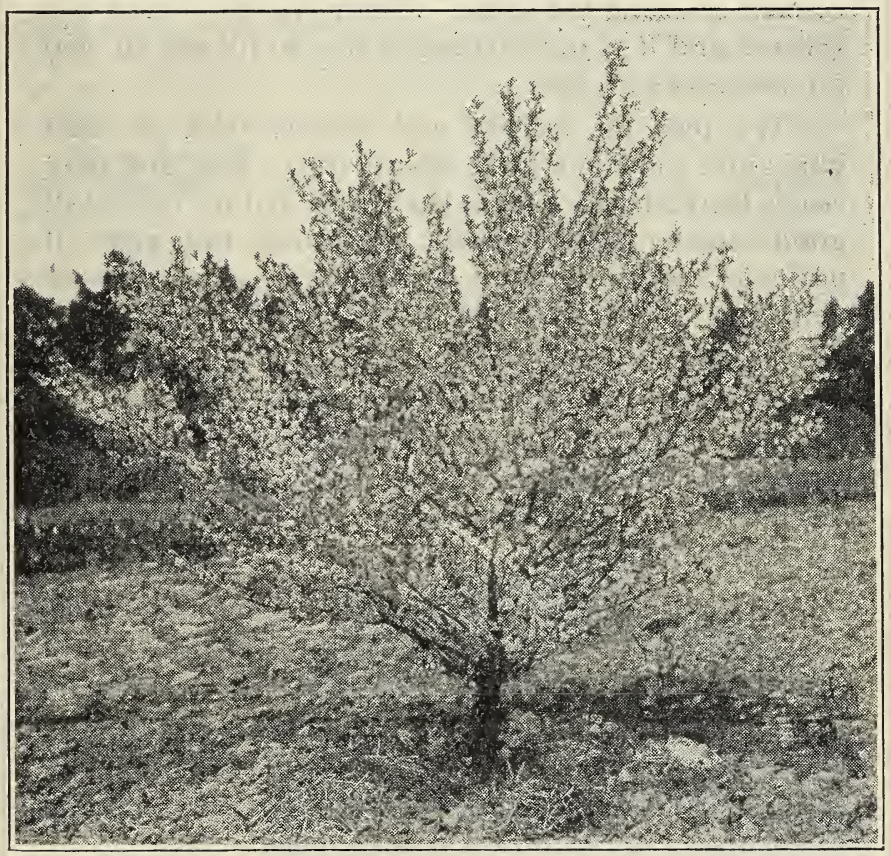

COMPASSS CHERRY IN BLOOM

C. A. Chinberg

C. A. Carmen
Wm. Strubel Chas. Hein

Hankinson Nursery Co. Hankinson, North Dakota 


\section{A WORD TO OUR FRIENDS AND PATRONS}

T IS our aim to grow and offer only the hardiest and best stock adapted to the Northwest and to do all in our power to have our customers succeed in growing the same. Their success means our success and it is our sincere desire to please all who do business with us.

We pay all freight and express charges and guarantee the stock to be first class. We are ever ready to rectify any mistakes if notified on receipt of goods and to replace stock that does not grow if notice is sent us before August first after date of delivery.

TERMS. One-fourth of the cash amount must accompany every order when booked, balance to be paid on receipt of goods. Privilege of examining stock always allowed. Prices quoted include boxing and packing, also freight or express charges to your nearest railroad station.

VARIETIES WILL BE FILLED,five of each at ten rates, fifty at hundred rates and five hundred at thousand rates.

ALL ORDERS are filled in rotation as received so get your orders in early while assortments are at their best. Notification cards are sent on receipt of order also when shipment is forwarded.

CONTRACTS taken for laying out and planting Private Grounds, Orchards and Commercial Fruit Gardens. If you contemplate planting an orchard or a fruit garden send us your list and we will figure on it. We give liberal discounts on large orders and make a specialty of this kind of business.

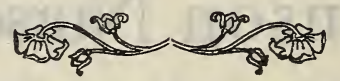




\section{APPLES}

\section{Standard Northern Varieties}

The following list comprises varieties that have either originated in the northwest or have been introduced from Russia. They are varieties that have been tested in the northern states and are now planted in this section.

Anisim. Season November to January. Tree spreading and a prodigious bearer; unusually free from blight and about equal with Wealthy in hardiness. Fruit medium to small, roundish; color, greenish nearly covered with dark red, over which is a bluish bloom; flesh white, juicy, fine grained, pleasant sub-acid. Beautiful when well ripened.

Charlamoff. Season August to October. Tree spreading, vigorous and productive. Fruit above medium to large; light yellow with crimson stripes aud splashes; flesh white, fine grained, pleasant flavor; often stained with red next to skin.

Duchess (Duchess of Oldenburg). Season August and September. Tree upright, vigorous, an early and annual bearer of uniformly large crops. Fruit large, greenish yellow with red stripes; flesh light yellow, medium fine grained, firm; flavor a pleasant acid; a great cooking favorite and prime market sort. Duchess is a good shipper for an early apple and commands good prices. Should be found in every orchard, large or small.

\section{Grundy.} Origin I o w a. Season September to November.

\section{Hibernal.} $\mathrm{S}$ e a s o n November, December. Probably the hardiest of the Russian apples adopted by many prominenthorticulturist as a standard of hardiness. Tree, sturdy, vigoro u s; very spreading and productive. Fruit large to very large, ir-

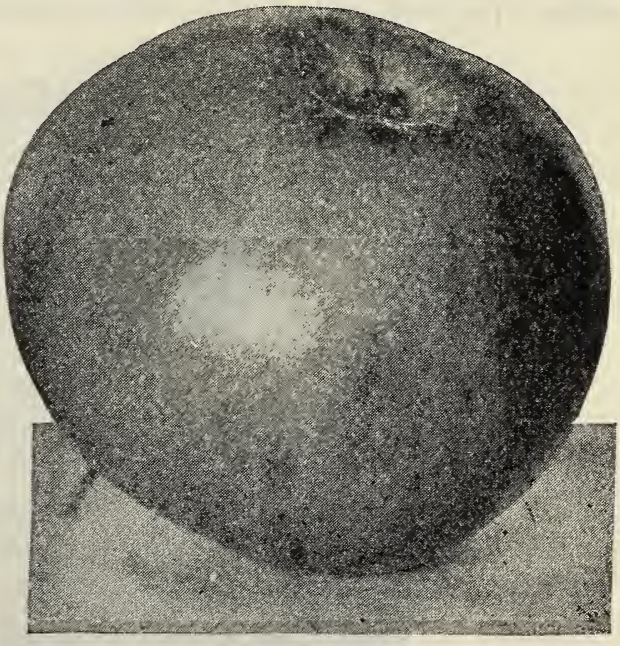

Hibernal

regular, greenish yellow with dull bronze red on sunny side; flesh acid, juicy, very good for cooking. 
Hutchins. October.

lowa Beauty. Originated in northern Iowa. Oblong, round, large; light with red stripes; sub-acid; quality very good; season early winter.

Jewell's Winter. Season January to March. Tree vigorous; an early bearer. Fruit hangs to tree in hardest winds-a valuable feature. Fruit medium; surface yellow with rosy crimson blush on sun side; flesh white, tender, crisp, juicy, pleasant, mild sub-acid, flavor good. One of the best late keeping varieties for northern orchards.

$\checkmark$ Judson. March.

Longfield. Season October to December. Fruit medium; shady side yellow with greenish bloom, sunny side yellow and red; flesh white, fine grained and of excellent aromatic flavor; juicy, sub-acid.

Malinda. Season February to March. An irregular but steady grower of about same hardiness as Wealthy. Wherever grown in Minnesota it is giving satisfaction as a long keeper. Fruit medium; green with blush of brownish red: flesh hard, medium fine grained; flavor sub-acid and good.

Maple. August.

McMahon. Season October to December.

Maiden Blush. September and October. Pale yellow with red check, tender and pleasant but not highly flavored.

Northwestern Greening. Season December to March. Fruit large to very large; green, becoming yellowish green when ripe; flesh yellow, fine grained and firm: flavor a good

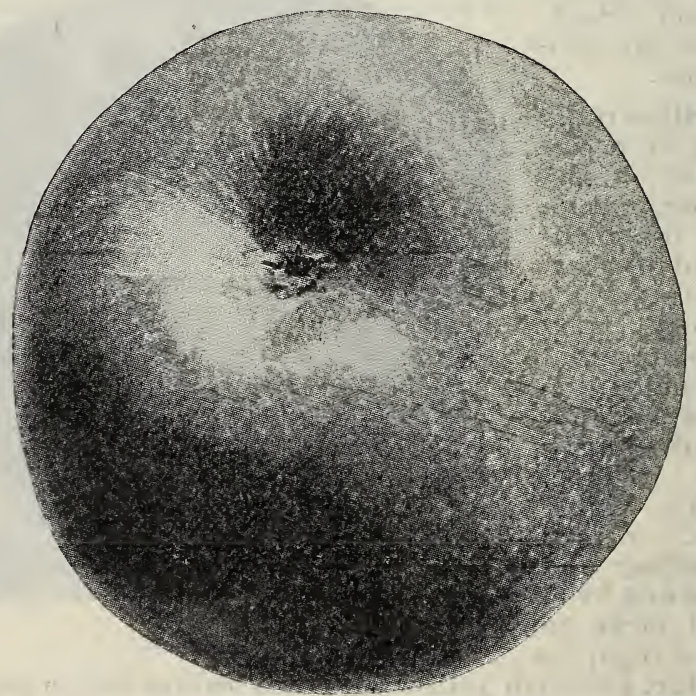

Patten's Greening 
sub-acid; very smooth and attractive. Should be given plenty of room in the orchard to secure large, even fruit.

Okabena. Season September to November. Vigorous, absolutely hardy and an ideal orchard tree in every respect. Bears very young. Fruitmedium to large; yellow striped and splashed with carmine which is heavy on sun side; flesh yellowish white, fine grained, crisp and juicy; flavor sprightly sub-acid; quality excellent. Ripens after Duchess and valuable in market on that account.

Patten's Greening. Season November to January. Fruit large to very large when well grown; green with often a blush of red or brown; flesh yellowish white, rather course but firm; core small; flavor a pleasant acid. Tree vigorous and spreading and exceptionally hardy; an early and regular bearer.

\section{Peerless. Season October to December.}

Fhœebe. Jaruary.

Radiant. This splendid variety is a cross between the Duchess and the Wealthy. It partakes of the characceristics of both. The tree is more hardy than the Wealthy. Does not blight with us. Fruit is large in size, oblong; handsome color-green, striped with crimson. A remarkable apple to hang on the tree, stem being thick and strong, seldom drops even in the hardest wind. It is a good market apple-commands a good price; keeps until December.

Scott's Winter. Season December to February. Fruit small to medium; color deep red over yellow ground; flesh yelliowsh white, course grained, juicy; small core; flavor pleasant acid, good.

Tama. February to March.

Tetofski. Season August. One of the earliest apples to ripen in the northern states. Fruit small to meáium; light yellow, striped and splashed with red; flesh white, tender juicy; flavor sub-acid, extra good quality. Tree stout and upright in growth.

Talman Sweet. Season December to March.

University. Season November and December. Fruit large, very regular; surface a clear yellow on sunny side; core medium, flesh white with yellow veinings, flavor pleasant sub-acid, quality good; tree hardy.

Wealthy. Season October to March. Almost too well known to need description. Since its origination by the late Peter M. Gideon in 1861, it has rapidly spread over the entire country until now it is extensively planted in all the apple growing states. Fruit large, regular, smooth, light yellow wlth crimson stripes and splashes; flesh white, often stained with red, tender, very juicy, sprightly sub-acid with delicious aroma. Splendid eating, dessert and cooking apple. Market demand never filled. Minnesota is justly proud of this variety.

Walbridge. Season January to March. 
Wolf River. Season October to January. One of the very largest apples grown in the North. Color yellowish green with stripes and splashes of carmine; very handsome and showy; flesh nearly white, firm and rather course grained; flavor sub-acid, fair to good.

Yellow Transparent. Season early August. One of the very earliest apples. Fruit medium; smooth transparent skin; clear white, becoming pale yellow when fully ripe; flesh white, tender, fine grained, of splendid quality.

\section{CRABS}

The following varieties of Crabs are especially recommended for planters in all sections.

Alaska. Fruit good; rather large for a crab; tree hardy.

Beach's Sweet. Season September.

Dartt (Hybrid). Season September to October. A vigorous, extremely hardy and ideal orchard tree. Fruit large for a hybrid-yellow ground covered with rich red stripes, underlaid with lighter red on sunny side; flesh yellow, medium fine grained, sub-acid.

Early Strawberry. Season early August. An oldtime favorite, especially in the Northwest. Fruit medium, greenish yellow ground overspread with carmine stripes and splashes; flesh nearly white; flavor mild, sweet, very good. One of the best eating crabs.

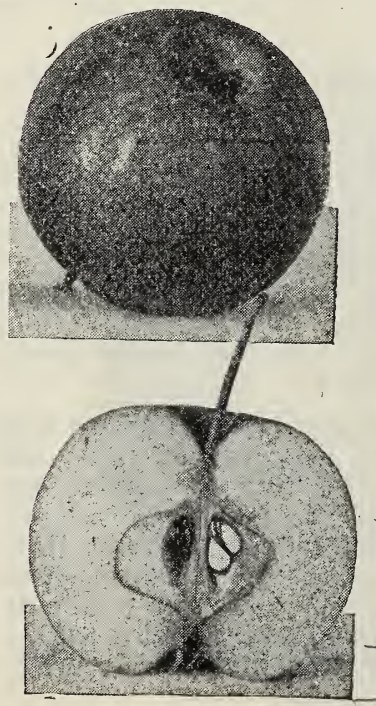

L yman's $\mathrm{P}$ rolific.

Excelsior. September. Medium, red, of good cooking quality; well known.

Faribault (Hybrid). October and November. A large handsome hybrid, red over greenish yellow ground. Tree upright, vigorous, hardy; very free from blight. A splendid variety. ust.

Florence. Season late Aug-

General Grant. October, November. Large yellow; red stripes; flesh white, sub-acid.

Gideon No. 6. Origin Minnesota. September. Has been renamed Mary.

Hardin. November.

Hiller. Season September and O.ctober. 
Hyslop. Season October to December. Fruit medium; heavy shadings of deep crimson and splashes of maroon; flesh fine, firm, yellow, astringent; bears abundantly in clusters which makes the tree exceedingly ornamental.

Lyman's Prolific. Season September to October. Fruit large, yellow and red, stripsd and splashed; flesh yellow and rather fine; of first-class cooking and preserving quality.

Minnesota (Hybrid.) Season October to January. One of the most desirable, bears liberally with age and is growing in favor. Fruit large, light yeliow, often splashed or mottled with blush on sunny side when allowed to fully ripen; flesh cream white, fine grained, juicy; flavor mild sub-acid and slightly aromatic. Delicious to eat out of hand and particularly desirable for culinary purposes.

Orange(Hybrid.) Season October. Fruit, large, even, light orange when ripe.

Pickett's Prolific (Hybrid.) A favorite on account of its good, firm shipping quality and the hardiness of the tree.

Quaker Beauty. Nurthern Iowa.

Siberian. Fruit small, round; flavor sour-still it is excellent for jelly and canning. A free grower and handsome; very hardy. ber.

Sweet Russet (Hybrid.) Season August and Septem-

Tonka. September.

Transcendent. Season September. Fruit medium to large; color brownish yellow with blush of carmine; flesh firm and crisp, yellowish, fine grained, very juicy, acid; fine for jelly.

Whitney (Hybrid.) Season August and September. Fruit large to very large for a hybrid; yellow, striped with red and mostly covered with red on sun side; flesh yellow, very juicy, and fine grained; flavor rich and almost sweet.

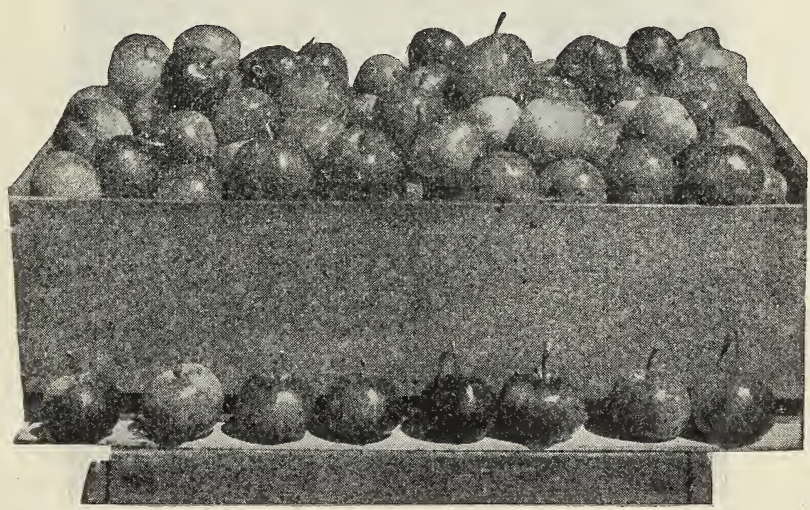

Transcendent Crab 


\section{PLUMS}

The Plum is the great native tree fruit of this northern region and the improvement which the native varieties have made under cultivation makes it equal in importance to that of the apple.

In productiveness the native plums are unsurpassed by any other class of plums or indeed by any tree fruit. In fact the tendency of nearly all varieties is to over-bear which however is easily overcome by judicious thining before the fruit is developed. They are all very regular in bearing and a good crop may be expected each season if proper care is given to the tree. No other fruit tree in this or any other section of the country is more easy of culture, when once it is understood, than is the plum of native origin. Unlike the apple, these plums have been here in this climate for hundreds of years and are so constituted in root, branch and fruit bud that the extremes of our seasons do not injure them. Thus the grower has only the matter of proper culture to contend with as the best varieties are thoroly hardy.

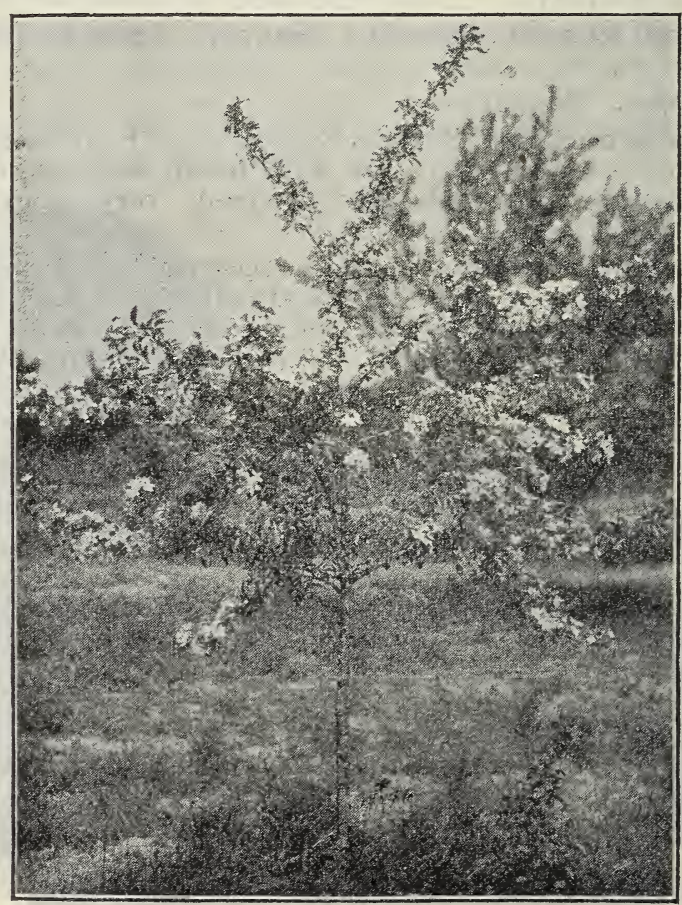




\section{Select Varieties of Hmericana Plums}

There has sprung up a long list of native varieties and we present below those which have been more thoroly tested and found superior by actual commerical growers in the North. We have therefore eliminated from this list many varieties of real merit as we find the average planter prefers to order from a list restricted to the best varieties and thus varieties "just as good" or "not quits so good" are here dropped.

Aitkin. Has the most northern origin of any commercial plum and is also one of the very earliest to ripen, fully two weeks before DeSoto. Fruit large, greenish yellow, ground covered with brilliant red, turning to dark red when ripe. Suitable for the extreme North.

Bursoto. Said to be hybrid of Burbank and DeSoto.

Cheney. Fruit irregular, oval, medium to large.

Season early.

Desoto. Probably the most grown of any plum of the Americana group. Productiveness almost too great; tree should be thinned to prevent overbearino and improve size of fruit. Season medium. Fruit medium; oranoe overlaid with crimson; flesh yellow and firm; of fine flavor and quality.

Forest Garden. Fruit large, nearly round, dull purplish red with thin bloom; flesh vellow, sometimes reddish next to the stone; firm, sweet and of pleasant flavor; cling. Season medium.

Free Silver (Terry). Originated in northern Iowa. One of the largest and finest native plums that has been introduced. Ripens very evenly.

Hawkeye. One of the largest and best plums grown in the Northwest. Fruit large, round, oval, thick skin that bears handling; color dull red over yellow; flesh yellow and of prime quality. Bears young and reported everywhere as prolific and regular.

Krikon. Imported from Sweden in 1901. Is one of the few blue plums that can be successfully planted in southern Minnesota. The tree is upright and requires but little pruning. Branches low, well adapted to open localities. Fruit medium size; pit very small; skin thin; meat solid; very juicy and sweet.

Ocheda. A variety discovered and introduced by $\mathrm{H}$. J. Ludlow, Worthington, Minn., (who was also the originator of the of the famous Okabena apple.) Size medium; dull, finely mottled red with rather thick bloom; flesh rich yellow; sweet and rich in quality; skin medium thick and without harshness; stone semi-cling. Season medium.

Peach. One of the sweetest of all the Americana plums. Size medium; color dark red. Tree hardy; excellent grower. Season medium.

Rollingstone. Size medium to large, (overbears like DeSoto and snould be thinned to secure large fruit.) 


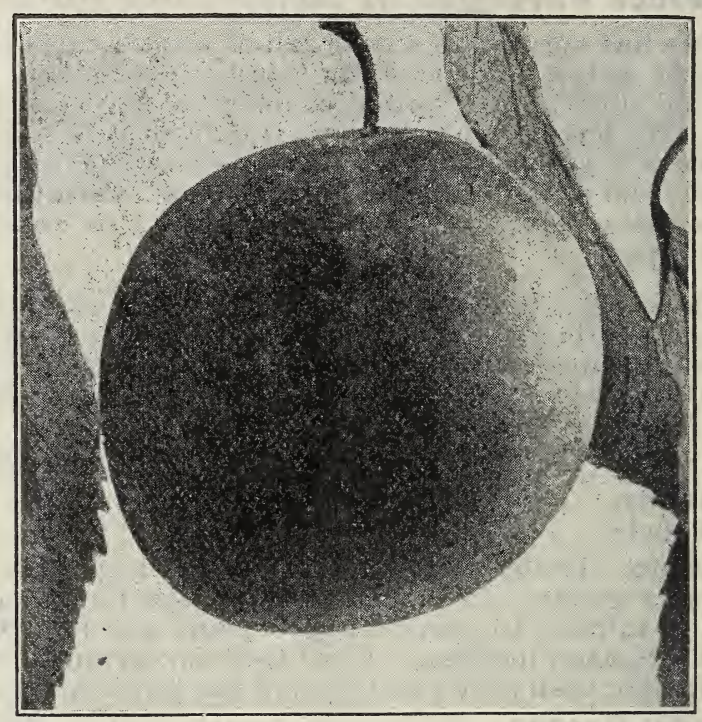

Surprise Plum

Surprise. Fruit large to very large; skin medium, thick, tender; bright red; flesh pale yellow, meaty, fine flavor; quality extra good. Season medium. In our opinion one of the very best for North Dakuta.

Stoddard. Color pinkish red over yellow, with very small white dots and blushish bloom over all. Season medium early.

Wolf. No western native has perhaps been more generally commended than this. It is pronounced productive and regular in bearing from southern Iowa and Nebraska to Stonewall, Manitoba, and appears to be generally satisfactory. Fruit round-oval, large; color crimson over orange, prettily dotted, with bluish bloom; flesh yellow and of good flavor and quality; stone perfectly free. Season medium. Tree beautiful and symmetrical; inclined to overbear. Very popular in market.

Wyant. Fruit medium to large; color purplish red, inclining to orange on shaded side.

Weaver. One of the few free stone plums that are hardy enough to be commercially successful in the north. Has been well tested, under cultivation since 1875 , and widely distributed thruout the northwest. Fruit, large, oval, color orange heavily overlaid with red; skin thick with light bluish bloom; flesh firm clear golden; quality rich, splendid. Season medium late. 


\section{Compass Cherry}

Probably no variety of stone fruit grown in the northwestern states has attracted more attention than the Compass Cherry. It is a cross between the Sand Cherry and the native wild plum.

The Compass Cherry is absolutely hardy. of our stock of this variety is grafted on hardy wild plum roots, thus making every tree "iron clad" in root and branch. (We wish here to warn planters that some growers are selling Compass Cherry budded on peach roots and Myrobalan plum stock. Such trees are worthless in this climate.)

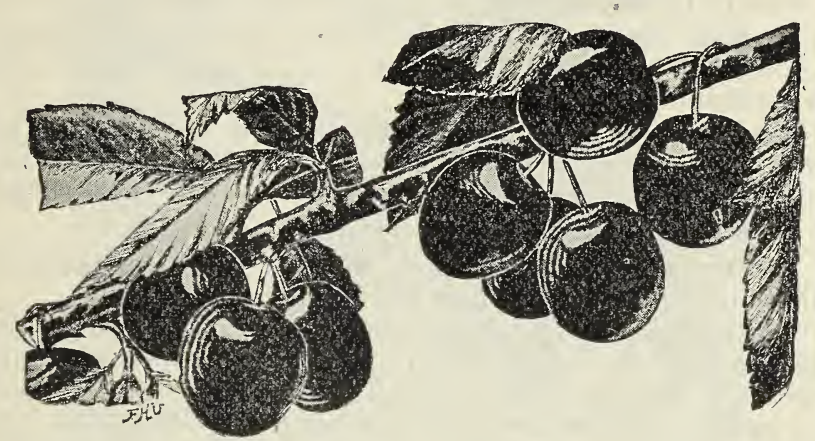

Fruiting Branch of Compass Cherry

Its early bearing is remarkable. A great many two year old trees as they stand in the nursery row are found with cherries on them and we bear constantly from buyers that many trees fruit well the same year they are set out.

In hybridization, the Compass largely lost much of that astringency near the skin so characteristic of the Sand Cherry. The amalgamation seems to have considerably developed the tender flesh and juiciness characteristic of the cherry. In shape, size and coloring of the fruit, the characteristics of the plum and cherry are about evenly divided. When young and green the fruits have more the appearance of undeveloped plums, but as they mature they fill out and become more round like the cherry. In color it changes from green to a bright red, deepening as it becomes ripe. For canning the Compass is valuable in this latitude, and when rightly preserved makes an excellent stock for pies, puddings, sauces, etc. While it fills a unique place in the north, where it stands today as the principal hardy fruit approaching the cherry, it is not to be compared with the well known commercial cherries grown in our eastern and central states. 


\section{CHERRIES}

The following are selected varieties, desirable for general culture in sections where they are hardy. The heart and Bigerreau are so designated and those followed by an "M"' belong to the Duke and Morello class.

Black Tartarian (Heart.) Very large. Late June and early July.

Early Richmond [English Pie Cherry] (M). Probably the most popular variety of the central states. Exceedingly productive and regular in bearing where hardy. Fruit dark red, medium to large. Unsurpassed for pies, puddings, etc. June.

English Morello(M). An old and popular variety. Homer $(\mathbf{M})$. A valuable seedling variety originating at Homer, Minnesota. Distinctly of Morello type. Season medium.

Kentish (M). A variety resembling the Early Richmond, and may possibly be a seedling. Seems to be hardier and the fruit somewhat smaller. A fine pie cherry.

Luelling (Heart). Large shiny black.

Montmorency Ordinaire (M). A beautiful large red cherry; of finer quality than Early Richmond.

Sand Cherry. Properly speaking, this variety belongs more among the ornamental shrubs than the cultivated cherries. We list it here as it has been found very desirable in the extreme parts of Minnesota, Manitoba, etc. Now practically superceded by the Compass Cherry-Plum which is described elsewhere in this catalog.

Ostheime (M). Fruit large, nearly black when ripe; flesh juicy and rich, fine for both dessert and cooking; finds ready sale on all markets. One of the most productive.

Wragg ( $\mathbf{M}$ ). Originated in Iowa and is very porular in the west.

Windsor (Bigarreau). A seedling introduced from Canada.

\section{GURRANTS}

The currant is an indispensable garden fruit. It is very largely planted all over the north, and owing to its early ripening season, it is grown successfully as a commercial fruit in all sections.

\section{Red Varieties}

Cherry. Bush vigorous, stocky and compact; cluster rather short, fruit medium large; color bright red; very thin skin; juicy and fine flavor; one of the most productive.

Long Bunch Holland. One of the best late varieties. 


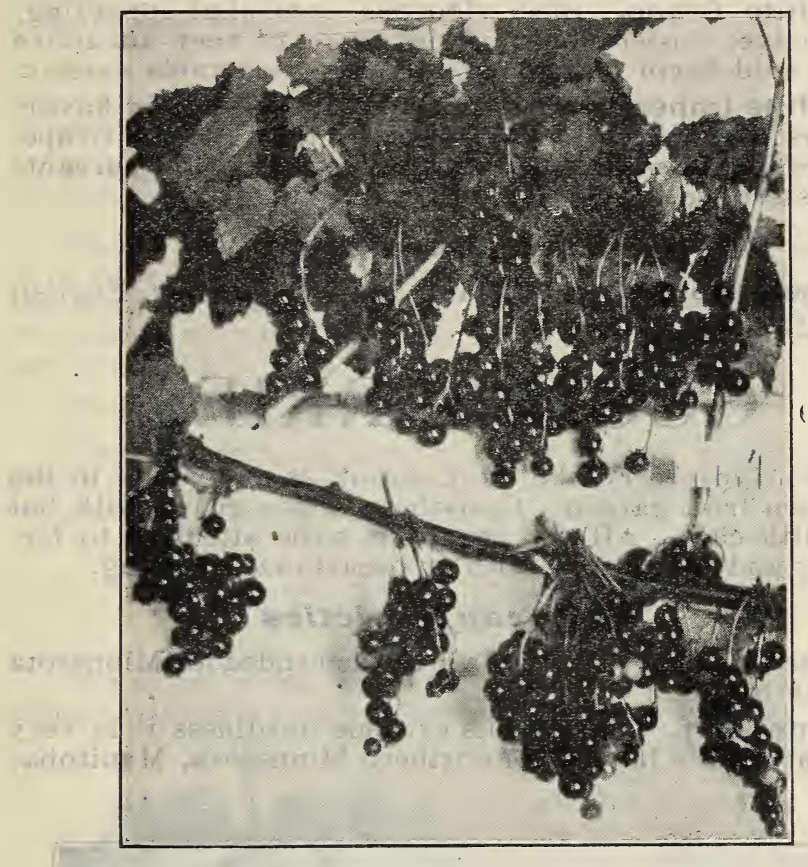

Perfection Currant

North Star. Popular on account of its hardiness, vigorous growth, early fruiting and productiveness. Fruit is borne on naked stems which makes easy picking.

Perfection. The latest introduction, being a cross between Fay's Prolific and White Grape, combining the best qualities of both. Berry bright red and large. The clusters average longer and the size of berry is maintained to the end of bunch. In quality it is said to be superior to anything in the market today, being of a rich, mild subacid flavor with plenty of pulp and few seeds.

Prince Albert. Bush vigorous, very upright in habit.

Red Dutch. An oìd and well known standard variety. Bush is a strong, upright grower and very productive everywhere.

Victoria. One of the most valuable varieties; very productive. Late. 


\section{White Varieties}

White Grape. Bush vigorous, somewhat spreading, productive; clusters long; berries large; of very attractive color, mild flavor and good quality; a good table variety.

White Imperial. Mildly acid and pleasant in flavor; clusters larger and longer stemmed than White Grape. The best of the white currants and the best of all currants for dessert use.

\section{Black Varieties}

Lee's Prolific. An old and always popular English variety.

\section{GOOSEBERRIES}

The Gooseberry like the Currant, is a favorite in the Northern fruit garden. Gooseberries are grown with but very little care. All they require is some attention to fertilizing and cultivation, with an occasional spraying.

\section{American Varieties}

The following varieties are recommended for Minnesota and the North.

American. Owing to its extreme hardiness it is very popular in the latitude of northern Minnesota, Manitoba, etc.

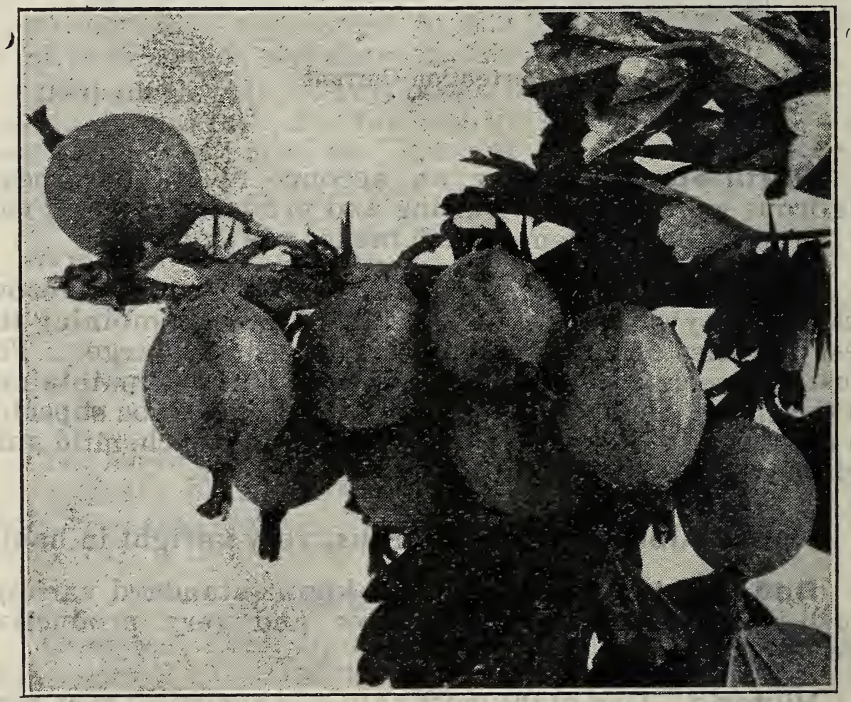

Pearl Gooseberry 
Carrie. Originated in Minnesota. Fruit red. After the third year, bush loses its thorns; very heavy bearer, medium size, excellent quaiity.

Downing. A seedling of Houghton. Large and handsome, pale green berry; of splendid quality for dessert or cooking. Bush vigorous and exceedingly productive.

Houghton. An enormously productive and always reliable, old variety.

Pearl. Similar to Downing but fruit generally reported a little larger. Said to be a cross between an English and American variety. Very hardy; free from mildew and productive, even more so than Downing. Superior in size and quality.

Red Jacket. Free from mildew.

Transparent. A strong and vigorous grower of superior quality. A popular variety in the north. Free from mildew. Season medium; size large.

\section{GRAPES}

The grape is an article of food as well as a luxury. Some varieties may be successfully grown in every state.

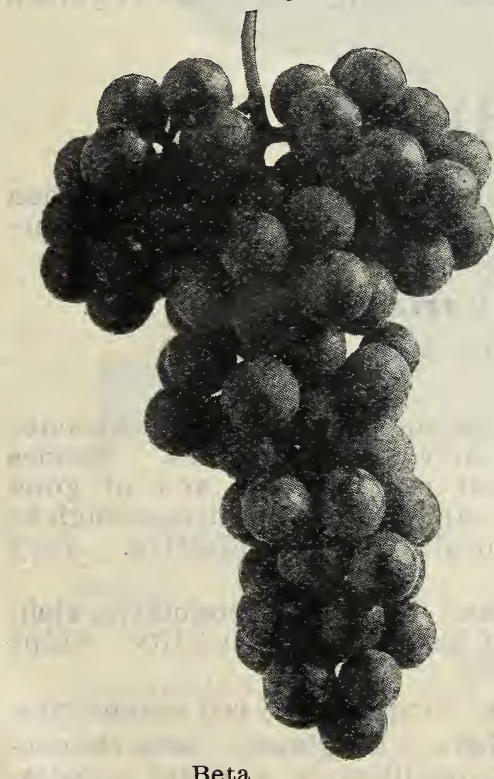

Beta In Minnesota and the Dakotas, many of the standard grapes may be fruited, a very little attention being given to winter protection.

\section{Black and Purple Varieties}

Beta. A hybrid of wild grape, probably crossed with Janesville, having same hardiness and general qualities of the wild grape. Has perfect flowers, may be depended upon to bear f $r u$ it $w$ he $n$ properly trained. Fine for wine, jellies, etc.

Campbell's Early. Bunch large shouldered. Ripens very early.

concord. The most popular grape in America.

Early Ohio. Ripens with Moore's Early. 
Janesville. Has long been regarded as the hardiest of cultivated grapes. Originated in central Wisconsin. Bunch medium, very compact; berry medium, skin thick; flesh pulpy, moderately juicy and highly flavored. Very strong rank grower and very productive.

McPike. New. Said to be a seedling of Worden.

Moore's Early. Bunch rarely shouldered, medium to large; berries much like Concord in flavor and quality but average larger. Ripens so early as to be nearly out of market before the Concord.

Wilder. Bunch and berries large.

\section{Red Varieties}

Brighton. Buncb and berries medium to large, sweet, with scarcely any pulp; and is conceded one of the best early red grapes.

Delaware. This is regarded by many as the best American grape.

\section{White, Yellow and Green Varieties}

Martha. White, sometimes turning pale yellow when fully ripe. Ripens with Concord.

Niagara. Bunch very large and handsome. Ripens with Concord.

Pocklington. Pale green, usually with tinge of golden yellow on sunny side.

\section{RASPBERRIES}

The Raspberry is a valuable and easy grown garden fruit. It is successful in most northern states and unsurpassed either as a fresh fruit or for preserving.

\section{Red Varieties}

Cuth bert. (Queen of the Market.)

Herbert. Very hardy.

King. Many of our leading fruit growers consider this one of the best of the early red raspberries. Berries large and attractive, bright red in color and of good flavor. Ripens with the earliest and is firm enough to ship well. The canes are healthy and productive. Very hardy.

Loudon. Its large and beautiful, productive, rich, dark crimson berries are of fine flavor and quality. Ships well, and vigorous in growth.

Marlboro. One of the largest early red raspberries.

Minnetonka (Ironclad). Originated near Minneapolis. In that and other localities is a great success. Said to be a heavy bearer; fine quality; good shipper; considered hardy. 
Sunbeam (South Dakota). Originated by Prof. Hansen of the Experimental Station at Brookings, S. D. Said to be the most hardy red raspberry grown. Very heavy foliage; is a shy bearer; quality fair; medium size. Not desirable where other and better varieties can be grown.

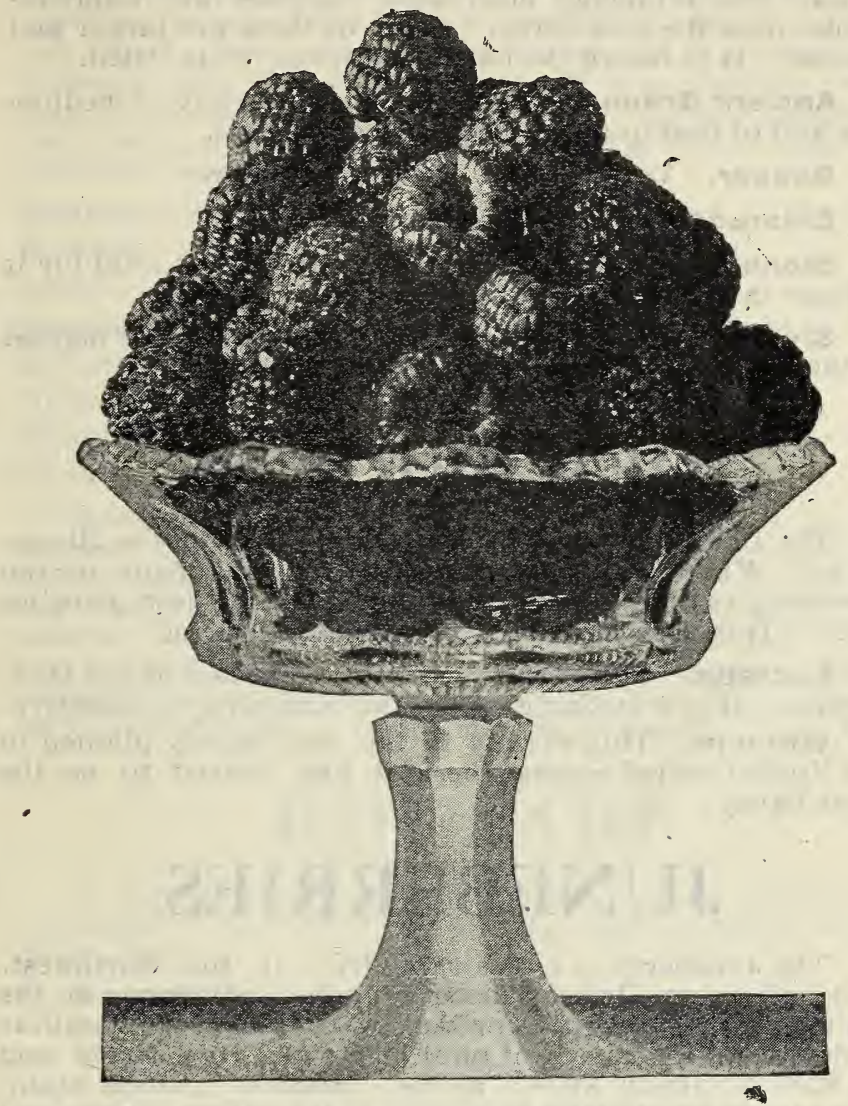

Loudon Red Raspberry

\section{Black Varieties-"Black Caps"}

Cumberland. Very large and very similar to Gregg. Gregg. One of the oldest and best known black caps. Ohio. (Early Ohio.)

\section{Purple Varieties}

Columbian. At this time regarded as the best variety of the class.

Schaffer. A standard variety.

\section{Yellow Varieties}

Golden Queen. A seedling of the Cuthbert and fully equal to that variety in vigor of bush and productiveness. 


\section{BLACKBERRY}

The Blackberry is a native fruit in all the northern states. The following cultivated varieties are improvements over the wild berry. Most of them are larger and sweeter. It is one of the hardiest garden fruits listed.

Ancient Briton. A reliable market variety of medium size and of best quality. One of the hardiest.

Badger. Very prolific; a vigorous grower.

Eldorado. Of late introduction.

Stone's Hardy. Its hardiness will always hold for it a place in the estimation of the northern planter.

Snyder. Also one of the best blackberries for market in the north and in hardiness second to none.

\section{DEWBERRIES}

The Dewberry is a dwarf, trailing form of the Blackberry. Where it is grown successfully, the fruit of the Dewberry is highly prized on account of its low growing habit. It is easily covered for winter protection.

Lucretia. One of the most widely planted of the Dewberries. It is a strong grower and exceeding productive.

Windom. This variety is the one mostly planted in the North Central States where it has proved to be the most hardy.

\section{JUNEBERRIES}

The Juneberry is a desirable fruit in the Northwest. The well known Dwarf Juneberry found indigenous in the latitude of Minnesota is prized by all who are familiar with it. An improvement on this has now been made and we have a variety known as the "Success" which maintains the characteristic hardiness of the native variety and has a much larger and finer flavored fruit. Perfectly hardy; needs no protection or special treatment.

\section{HORSE RADISH}

This popular plant was introduced to this country from Great Britian at an early date and its cultivation forms an important industry in many sections too well known for further descriptions. We offer strong roots which should be planted in the spring. 


\section{STRAWBERRIES}

The Strawberry is perhaps the most popular small fruit cultivated in the North. As is well known, many of our best varieties have imperfect or sterile blossoms. For this reason, when planting such varieties it is necessary to alternate them with staminate or perfect varieties in order that the blooms may become fertilized. In the following: list, the buyer will therefore find such varieties designated as either perfect or imperfect.

Bederwood-Perfect

Bubach-Imperfect

Clyde-Perfect

Crescent-Imperfect

Enhance-Perfect

Haverland-Perfect

Jewell's Improved

Lovett-Perfect
Miller-Perfect

Palmer-Perfect

Ridgeway-Perfect

Rough Rider-Perfect

Sample-Imperfect

Splendid-Perfect

Warfield-Imperfect

Wolverton-Perfect

Senator Dunlap-Perfect. One of the great market berries. Has now been well tested and proven wonderfully prolific and profitable everywhere. Plant is a rampant runner and should be restricted. One of the best in dry seasons. Fruit medium to large, regular in form, color bright, heautiful red, glossy; exceptionally firm, making a splendid keeper and shipper. Quality first-class; ripens early and continues a long time. Mid-season.

\section{RHUBARB}

A valuable early spring vegetable, the use of which is universal. The following are the best varieties now in cultivation.

Excelsior. A long growing and tender variety, with tender skin. Especially valuable for preserving.

LInnæus. One of the oldest and best known varieties; vigorous and productive.

\section{ASPARAGUS}

Conover's Colossal. Is probably the best known as it is the oldest named variety under cultivation. It is still said to be the most reliable in some locations as it is very vigorous and keeps the bed full of strong shoots.

Columbian Mammoth White. A distinct variety of mammoth size, great yield and superior quality. Remarkable for the clear whiteness of its stalk which retains the clearness of its color until several inches above the surface. 


\section{DECIDUOUS TREES}

Asto height, we have adopted the following classification which will give a fair idea of the comparative size of different species listed.

Lg. Trees usually attaing a height of 50 feet or more at maturity.

Med. Trees usually less than 50 and more than 25 feet at maturity.

Sm. Trees commonly less than 25 feet at maturity.

\section{ASH-Fraxinus}

White Ash. (F. Americana). Lg. A well known timber tree. It attains a large size and is of great value for timber. A good street tree in many sections, is a rapid grower. It produces a broad, round, head and has a straight clean trunk. While young, its foliage has a remarkably soft and mellow appearance.

Green Ash. (F. lanceolata). Lg. This species is of the greatest value in the prairie states of the Northwest. Altho not so tall a grower nor so rapid in growth, it is much hardier and better adapted to the extreme conditions of this section. It is valuable for street planting as a shade tree and for all kinds of prairie timber culture. Somewhat resembles F. Americana. Grows very fast when young and before it produces seed, after which its growth is, slower.

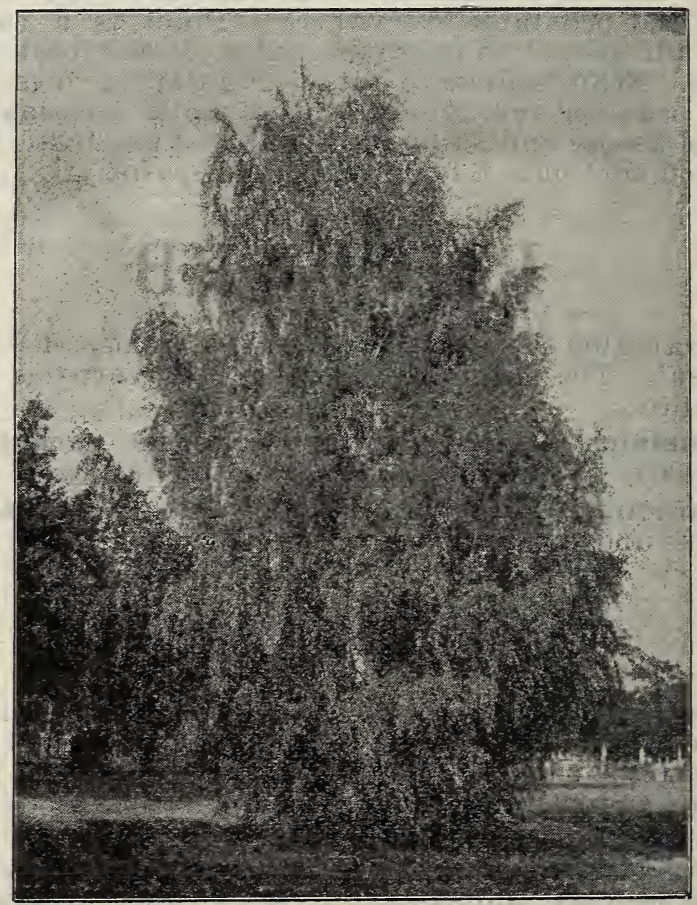

Weeping Cut Leaf Birch 


\section{BIRCH-Betula}

The Birches number among them some of our most beautiful and useful native trees. They are indispensable in park and lawn planting, and are also receiving more and more attention for street uses. It is primarily a tree of the North; in fact, no trees grows farther North.

American. White Birch, Poplar Birch. (B. populifolia). Med. A small or medium sized, graceful tree. Thrives well in even poor and dry soils. The bark is a grayish white.

European White Birch. (B. alba.) A successful tree even on light soils.

Weeping Cut-Leaf Birch. (var. pendula laciniata) Lg. This magnificent tree is, without question, the most popular and the most planted of all pendulous or so-called weeping trees. It is a tall, slender tree, yet of vigorous growth. It has an erect central trunk, somewhat pyramidal in shape with graceful, drooping branches and white bark on all the old wood. The foliage is fine, thin, deeply and delicately cut; and of a beautiful shade of green.

\section{BOX ELDER-Acer}

Box Elder, Ash-Leaved Maple. (A. Negundo.) Med. to Ler.

\section{BUTTERNUT - Juglans}

Butternut, White Walnut. (J. cinerea.) Very much resembles the Black Walnut. It is a moisture loving tree and succeeds best on low rich soils.

\section{CRAB-Pyrus}

Pyrus loensis. (var. Bechtel's Flowering Crab). Sm. One of the most ornamental varieties in the Pyrus group, and also one of the hardiest. Originated in Iowa. It is a better grower than the parent type, with good foliage. The flowers are double and very beautiful. They are a delicate blush or shell pink color and highly perfumed. This variety should appear in every collestion where it is hardy.

\section{ELM-Ulmus}

American White EIm, Water EIm. (U. Americana.) Lg. One of the most largely used trees for street planting and as a shade tree for lawns and parks. It is the most characteristic tree of this region and one of the most beautiful. Its habit is at once majestic and graceful, and the wide spreading tree, borne usually at a considerable height on a straight trunk, and affords ample shade and shelter.

Cork EIm, Rock EIm. (U. racemosa.) Med. to Lg.

Siippery EIm, Red Eim, Moose EIm. (U. fulva.) Lg.

Weeping American EIm. (var. pendula.) Med. A picturesque type of irregular growth with pendulous branches, more pronounced in their drooping habit than $U$. Americana. Should not be confused with the Camperdown Weeping Elm which is more pendulous and more uniform. 


\section{HACKBERRY-Celtis}

American Nettle Tree. (C. occidentalis.) Med. A rare native tree, with wide spreading head and numerous slender branches. The bark is thick and rough. The leaves are about the size and form of the apple tree, but more pointed and of a bright, shining green. In general appearance it very much resembles the Elm,

\section{LARCH-Larix}

European Larch. (L. decidua) Lg.

\section{LINDEN, BASSWOOD-Tilia}

American Linden, Basswood. (T. Americana.) Lg. A well known, stately tree with large, heart-shaped leaves of a pleasing green color. A vigorous grower of pyramidal habit when young but eventually a large, round headed tree. A valuable lawn tree and should be more used for this purpose.

European Linden. (T. ulmifolia).

\section{MAPLE-Acer}

Ginnala Maple. (A. Ginnala). Sm. A graceful, shrublike tree, bright red in autumn.

Norway Maple. (A. platanoides). Lg. A fine and handsome tree from Europe, with round, spreading head. The leaves turn a pale yellow in autumn, often highly colored, especially in the case of some of its varieties.

Schwedler's Purple Maple. (Schwedler's.) Med.

Silver Maple, Soft Maple. (A. saccharinum.) Lg. A well known ornamental tree, with wide spreading, slender branches. Has been much used as a street tree. It is valued for windbreaks on account of its quick, upright growth.

Sugar, Hard or Rock Maple. (A. saccharum.) Lg. A beautiful and always popular tree, growing on a smooth trunk and forming a dense, oval head. It is adapted to nearly all kinds of soil.

Wier's Cut Leaved Silver Maple. (var. Wieri.) Med.

\section{MOUNTAIN ASH-Sorbus}

American Mountain Ash, Dogberry. (S. Americana ) Med. A compact, oval headed tree.

European Mountain Ash, Rowan Tree. (S. Aucuparia.) Med. A round headed tree, twenty to forty feet high and occasionally more. It is ornamental all thru the season. In May and June the trees are covered with the large flat heads of pure white flowers, four to six inches across. These are followed by clusters of bright orange and red fruits which adorn the tree long after the frost has denuded it.

Oak-Leaved Mountain Ash. Sm. A hybrid variety of very distinct habit. 
Weeping Mountain Ash. (var. pendula.) Sm. The best tree of the extremely penduloustype for the North. The fruit and flowers are identical with S. Aucuparia. In habit, however, it is decidedly drooping, the branches taking an almost directly downward growth.

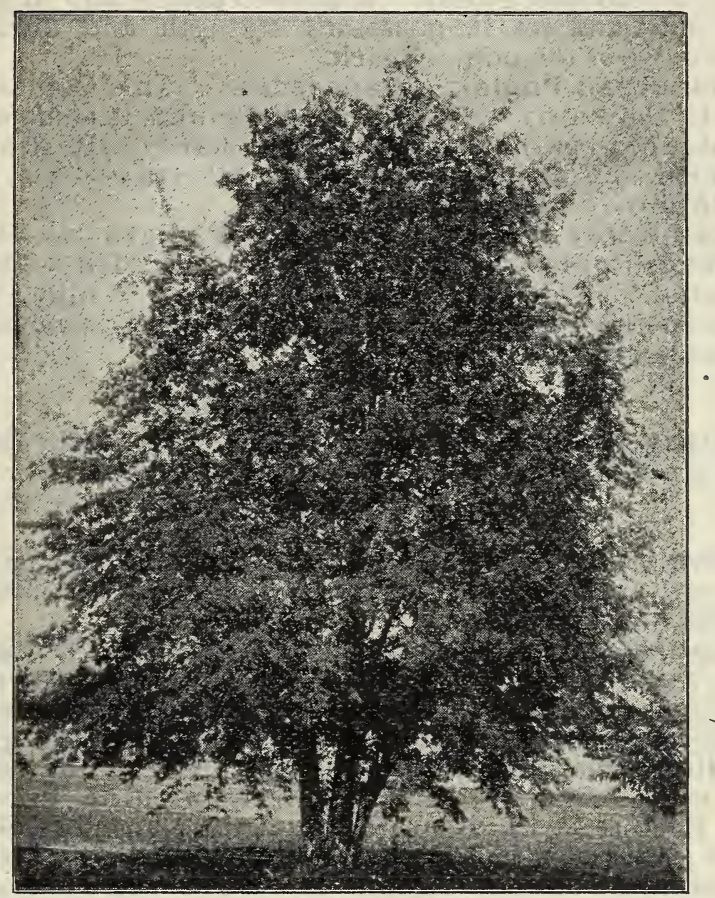

Mt. Ash

\section{MULBERRY-Morus}

Russian Mulberry. (var. M. alba. Tartarica.) Sm.

\section{OAK-Quercus}

Burr Oak, Mossy Cup Oak. (Q. macrocarpa.) Lg.

Pin Oak. (Q. palustris.) Lg.

White Oak. (Q. alba.) Lg.

\section{POPLAR, ASPEN-Populus}

The Poplars are a very important class of trees, especially in the prairie states of the Middle West where their rapid growth makes them popular for many purposes.

Balm of Gilead. (P. balsamifera var. candicans.) Lg. A good street tree. 
Norway Poplar. Lg. A very distinct tree in habit of growth and making a straight upright, somewhat pyramidal head. It is of extremely rapid growth, straight and regular in habit, which fact makes it particularly desirable as a quick growing street tree. The foliage is large, thickly borne, bright and glossy. It grows rapidly and in almost every soil, and yet it possesses strength and durability which most of the poplars lack.

Canadian Poplar. (Canadensis.) This Poplar is related to the hardy Cottonwood-resembles it somewhat in its habit of growth. It is extremely hardy. It grows as far north as Edmonton in northern A]berta.

Cottonwood. (P. deltoides.)

Lombardy or Italian Poplar. (P. nigra var. Italca.)

Silver Poplar. (P. alba var. nivea.) Med. The commonest and hardiest type of the Silver or White Poplar. It is sometimes called silver Maple from the resemblance of the foliage to that of the Maple.

\section{WALNUT-Juglans}

Black Walnut. (J. nigra.) Lg. One of the noblest trees of the American forest.

\section{WILLOW-Salix}

Golden Russian Willow, Yellow Willow. (S. vitellina var. aurea.) Lg. At the present time one of the most planted of all Willows.

Laurel Leaf or Bay Leaf Willow. (S. pentandra.) Sm. An ornamental variety of upright growth, forming a round head. Foliage is a deep shining green, closely resembling the Laurel. Thrives well on high or low ground.

Niobe Weeping Golden Willow. (S. vitellina var. pendula nova.) Med. A weeping or drooping form introduced from Europe by the South Dakota Experimental Station. It has graceful, drooping branches, and is of regular habit. The Station Bulletin says of it-One of the most promising novelties in recent years as there is need of a strictly hardy, weeping willow in the North for lawns, parks and cemeteries.

Wisconsin Weeping Willow. (S. Babylonica var. dolorosa.)

White Willow, Grey Willow. (S. alba.) Lg. A large tree with short and thick trunk.

\section{EVERGREENS}

From the standpoint of the horticulturist, the Conifers or cone bearing Evergreens take a very prominent place among the material for landscape gardening effects and in their more practical useas windbreaks. Their evergreen habit-for all except the Larches and Ginkgos are evergreen-and their conical form, especially in the early perinds of life. With a branch system persisting to the base of a long time are the elements which make them desirable

KEY TO SIZE

Lg. Trees usually attaining a height of 50 feet or more at maturity.

Med. Trees usually less than 50 and more than 25 feet at maturity.

$\mathrm{Sm}$. Trees commonly less than 25 feet at maturity. 


\section{CEDAR, JUNIPER-Juniperus}

Juniper Savin. (J. Sabina var. prostrata.) A unique, dwarf Evergreen of prostrate or almost creeping habit.

Red Cedar. (J. Virginiana.) Lg. The Red Cedar is indigenous thruout Minnesota and the entire Northwest.

\section{FIR-Abies}

The firs are of characteristic, tall, pyramidal habit and, altho resembling the Spruces in form, they are more regularly symmetrical. They are nearly all native of the northern country and more handsome in cultivation than in their native soil.

Balsam Fir. (A. balsamea) The best known species of this class. It forms a slender, spiral and very symmetrical pyramidal tree. One of the most rapid growing trees in the Conifer group.

White Fir. (A. concolor). Lg. A handsome species from the Rocky Mountains. One of the best Firs for hot, dry situations as this is the condition to which it is native.

\section{HEMLOCK, HEMLOCK SPRUCE-Tsuga}

Common Hemlock or Hemlock Spruce. (T. Canadensis.) Lg. The general description above should really be applied to this species as it is the best known and most commonlyplanted in the Northern States. It is one of our finest native Evergreens.

\section{PINE-Pinus}

Austrian Pine, Corsican Pine, Black Pine. (P. Laricio var. Austriaca) Lg. A European Pine of much ornamental merit. One of the most important Conifers for specimen or mass planting.

Dwarf or Swiss Mountain Pine, Mugho Pine. (P. montana var. Mughus.) Sm. A low spreading Pine and very useful in lawn planting.

Jack Pine. (P. divaricata.) Med. The most northern of all American Pines.

Northern Ponderosa Pine, Yellow Pine, Bull Fine. (P. ponderosa var. scopulorum.) Med. Forms a stout, spreading tree with branches often pendulous. A rapid grower.

Scotch Pine. (P. sylvestris.) Med. to Lg. This pine is one of the most important timber trees of Europe.

White Pine. (P. Strobus) Lg. Our native northern White Pine is famous as a stately and beautiful tree under a wide variety of conditions. 


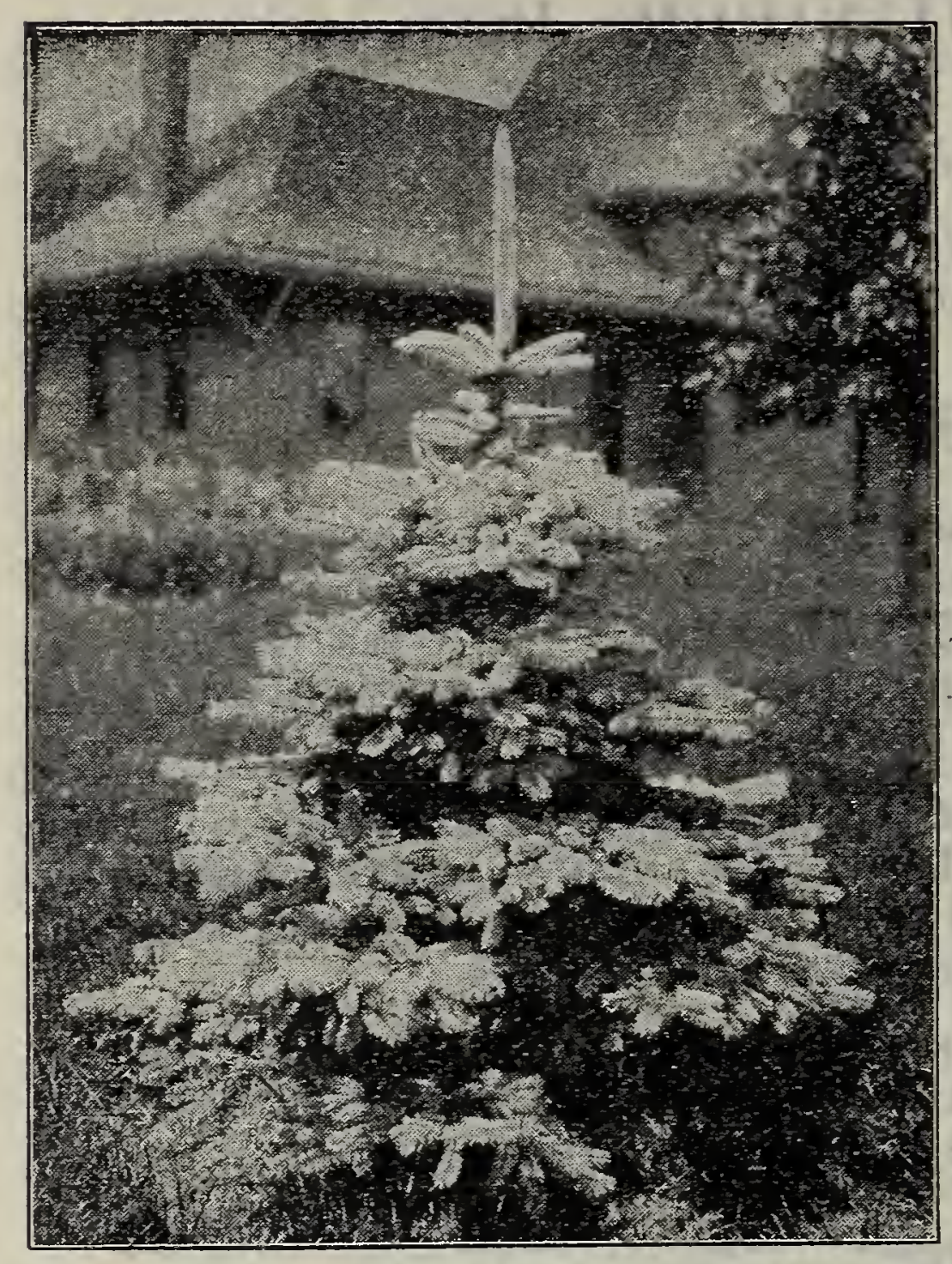

Colorado Blue Spruce.
SPRUCE-Picea

Black Spruce. (P. nigra) Med. It is of variable habit, sometimes attaining quite a height but mostly of medium size.

Colorado Blue Spruce. Med. to Lg. This noble species from the Rocky Mountains is without doubt the most striking and ornamental of the Spruces, if not of all Conifers. A dense growing, symmetrically pyramidal tree with stiff, pointed foliage, the needles being very thickly borne on the stem.

Norway Spruce. (P. excelsa) Lg. Of rather rapid growth and is a handsome tree with its graceful habit and dark green dense foliage.

White Spruce. (P. alba) A well known native tree and one of the most magnificent ornamental evergreens for all purposes.

\section{SPRUCE, DOUGLAS-Pseudotsuga}

Douglas Spruce, Red Fir. (P. Douglassi.) Lg. The only species well known in cultivation, and in its habitat thru the mountains of western North America it is one of the tallest and handsomest forest trees.

\section{Forestry and Shelter-Belt Stock}

The propagation of small stock for forestry planters. and flso those living on prairies where shelter belts are necessary. has always heen an important part of our business. We can supply the leading varieties of bath reciduous trees and evergreens that have been tried and found best adapted for these purposes.

Ages and sizes. For the most intelligent filling of orders for this class of stocls we have found it expedient to grade all seedlings and stock grown from cuttings according to height. We can supply in various ages, from one to three years in deciduous stock, and from two to ten years in evergreens. Among the deciduous varieties grown from seed. such as Ash. Box Elder, Maple, etc., we grade in regular sizes, running 12 to $18 \mathrm{in.,} 18$ to $24 \mathrm{in}$. high, etc.. and are prepared to furnish this stock in quantity. Among the evergreens we handle largel. transplanted stock ranging in size from 8 to $12 \mathrm{in}$. up to 3 to $4 \mathrm{ft}$. We can also supply seedling stock 8 to 10 in. high in Arbor.Vitæ, Balsam Fir. White Pine. Jack Pine and Black Spruce.

Space does not permit us here to enumerate the qualities of each separate variety as adapted to the shelter belt. 


\section{Ornamental Deciduous Shrubs}

\section{BARBERRY - Berberis}

Their orange and yellow flowers in May or June are succeeded by a small but highly colnied fruit. In many places are much used for hedging purposes. For this use they give the best effect when grown as a loose hedce and not sheared too closely.

European Barberry, Common Barberry. (B. vulgaris) 5 to $6 \mathrm{ft}$. An up-right grower with thorny branches and pretty, light green foliage. The yellow flowers of early summer are followed by dark red berries.

Purple-Leaved Barberry. (var. purpurea) Similar to $B$. vulgaris in habit but the foliage is a deep rich purple. Color is distinct and met with in few other shrubs or trees.

Thunberg Japanese Barberry. (var. Thunbergii) 2 to $3 \mathrm{ft}$. Of low, spreading growth, forming a dense bush.

\section{BUCKTHORN-Rhamnus}

Common Buckthorn. (R. Catharticus.) 4 to $6 \mathrm{ft}$. June-July. One of the best plants for ornamental hedges. Branches are thorny. It stands shearing well and is easily kept trimmed to any desired height and form.

\section{BUFFALO BERRY - Shepherdia}

Sherpherdia Argentea. The Western Buffalo Berry. $8 \mathrm{ft}$. A sturdy shrub native in the Dakotas and Manitoba. Valuable for use on soils that are not the best.

\section{CRANBERRY, HIGH BUSH}

High Bush Cranberry. (V.opulus.) 7 to $10 \mathrm{ft}$. June. Has handsome broad foliage of a lustrous, dark green color, changing later to rich coppery tints.

(var. nanum.) 2 ft. dwarf, bushy shrub with good foliage and valuable in grouping.

\section{GURRANT-Ribes}

Crimson-Flowered Currant. (R. sanguineum.) $3 \mathrm{ft}$. July. Deep red flowers produced in great abundance.

Gordon's Currant. (R. Gordonianum.) 4 ft. MayJune. A profuse blooming variety with crimson and yellow flowers in showy spikes.

Missouri Currant, Golden Currant. (R. aureum.) 4 to $6 \mathrm{ft}$. A native species with golden yellow flowers in showy racemes.

Mountain Currant. (R. alpina.) $3 \mathrm{ft}$. May. Dense, upright racemes of golden flowers. Fruit deep scarlet.

\section{DOGWOOD-Cornus}

An important genus of ornamental shrubs. most of them hardy and most of them particularly corspicuous for their brilliantly colored bark. Those with conspicuous bark are especially desirable in massed groups in contrast with other shrubs. Some of the varieties are also finding favor as hedge shrubs.

American Red Ozier Dogwood, Kinnikinnick. (C. stolonifera) 6 to $8 \mathrm{ft}$. This well known native of our northern forests is being more and more used in ornamental planting, especially in the northern states where its absolute hardiness is appreciated. 
Siberian Dogwood. (C. alba) 5 to $6 \mathrm{ft}$. A strong grower with erect and stout, bright red branches. Useful for shrubbery and for winter effects.

Yellow-Branched Dogwood. (

C. sanguinea. (var. elegantissima variegata.) 4 to 5 ft. One of the most desirable shrubs with variegated folliage.

\section{ELDER-Sambucus}

Common American Elder. (S. Canadensis.) 8 to 12 ft. A large spreading bush with handsome foliage.

Cut-Leaved Elder. (var. laciniata.) 5 to $9 \mathrm{ft}$

European Elder, Blackberried Elder. (S. nigra.) 6 to $10 \mathrm{ft}$. July.

Golden Elder. (var. aurea.) 5 to $8 \mathrm{ft}$. Bright golden yellow leaves.

Red-berried Elder. (S. racemosus.) 6 to $10 \mathrm{ft}$. May.

EUONYMUS--Strawberry Tree, Spindle Tree, Burning Bush

Burning Bush, Waahoo. (E.atropurpureus.) 8 to $10 \mathrm{ft}$.

Strawberry Bush. (E. Americana.) 5 to 8 ft.

\section{FORSYTHIA-Golden Bell}

Fortune's Forsythia. (F. Fortuneii) $8 \mathrm{ft}$. April and May . Bright yellow flowers.

(F. viridissima) $6 \mathrm{ft}$. May. A fine shrub for general use..

\section{HAZELNUT - Corylus}

Common American Hazelnut. (C. Americana.) 4- $8 \mathrm{ft}$.

\section{HYDRANGEA}

H. paniculata. (var. grandiflora.) 6 to 8 ft. August and September. The showiest of all autumn flowering shrubs, bearing immense heads of creamy white flowers which, with the approach of cold weather, turn to rich shades of pink and coppery red. The large individual flowers are sterile and the panicles remain intact long after the first frosts.

\section{HONEYSUCKLE-Lonicera}

This is an extensive genus of upright and climbing shrubs. They are free bloomers and of easiest culture. Many of them make admirable hedge plants and are being more and more used for that purpose. The climbing varieties will be found described under Climbing and Trailing Shrubs.

White Tartarian Honeysuckle. (var. alba.) 


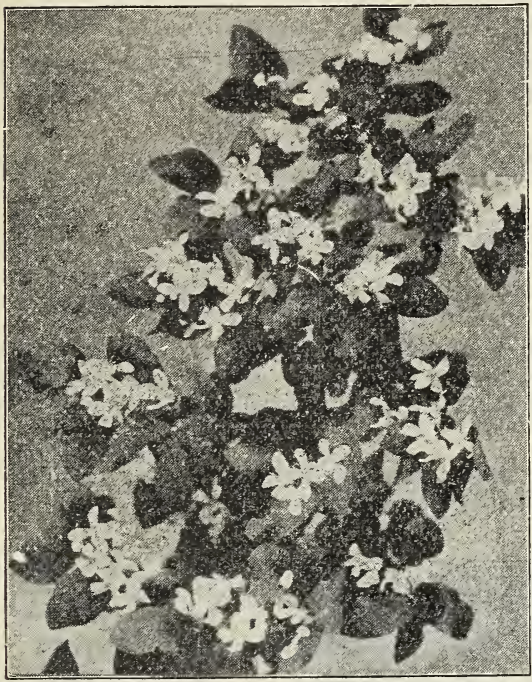

Lonicera Grandiflora

Morrow's Bush Honeysuckle. (I. Morrowii. )' $5 \mathrm{ft}$. July

Red Tartarian Honeysuckle. (var. grandiflora.)

Tartarian Honeysuckle. (L. Tartarica.) This is the best known variety in the western states and with its sub-varieties it can be found in nearly all ornamental plantings. The newer variations, var. splendens, var. grandiflora, etc., are so much superior to the old type that they are rapidly superceding it. All form vigorous upright shrubs from 8 to $12 \mathrm{ft}$. in height and are valuable for their flower and fruit alike. L. Tartarica proper has pink flowers in May and June.

\section{LILAC--Syringa}

As explained under the head of Philadelphus, this generic name should be used only in connection with the Lilac. In the past it has been used as a common name for some of the varieties of Philadelphus but there is no connection whatever between them as they belong to entirely different botanical orders. No other shrub as a class is perhaps so well known. A careful selection will offer a greatly extended season of blooming.

Common Purple Lilac. (S. vulgaris.) 8 to $10 \mathrm{ft}$. May. This is the oldest and best known type of the Lilac.

Common White Lilac. (var. alba.)

Siberian White Lilac. (S. Siberica alba. ) A vigorous growing variety with small and narrow foliage.

Hungarian Lilac. (S. Josikæa.) 6 to $8 \mathrm{ft}$. May. From Transylvania, violet purple flowers which appear very late.

Japan Tree Lilac. (S. Japonica.) 15 to $18 \mathrm{ft}$. Late June.

Persian Lilac. (S. Persica.) 5 to $6 \mathrm{ft}$. May and June. A very graceful form.

The following six grafted Lilacs we grow as being the finest of the improved varieties, representing the purple, red and white shades in both single and double flowers. 
var. Chas. X. Single. A reddish purple flower.

var. Ludwig Spæth. Single. A dark purplish red.

var. Madam Abel Chatenay. Double. Large panicles of double white flowers.

var. Pres. Grevy. Double.

var. Princes Alexander. Single. A variety of white flowers.

var. George Bellairs. Double. Red.

\section{OLEASTER, WILD OLIVE-Elæagnus}

Russian Olive or Russian Oleaster. (E. augustifolia.) 12 to $20 \mathrm{ft}$. Forms a large sized shrub or small tree. It is extremely hardy and succeeds well in very dry - locations.

Silver Berry. (E. argentea.) 5 to $8 \mathrm{ft}$. July. A native of Manitoba, Minnesota and Dakotas.

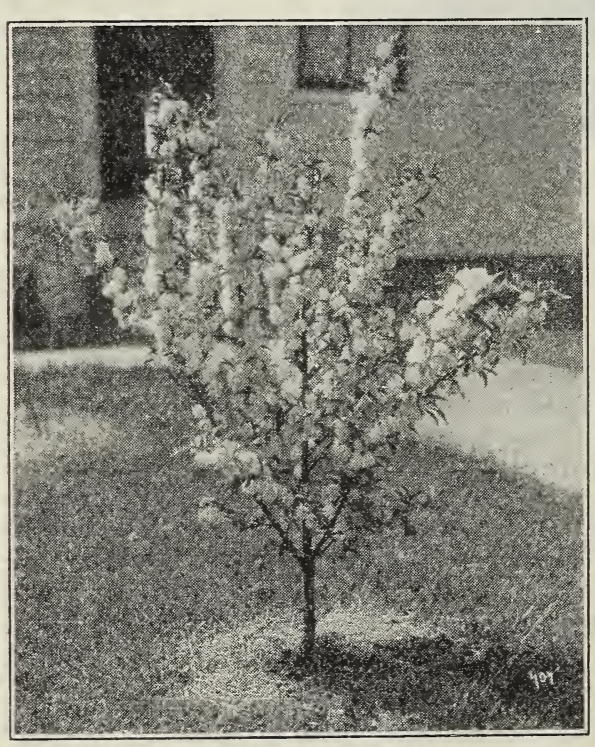

Flowering Almond
PLUM AND ALMOND Prunus

Double F I owering Plum. ( $\mathrm{P}$. triloba.) 4 to $6 \mathrm{ft}$. May. Alightpink, very double flower which completely surround and cover the branches so as to entirely hide them.

Double White Flowering Almond. (P. Japonica flore alba plenn.) $4 \mathrm{ft}$. May. Handsome, do uble white flowers in great profusion completely covering the branches.

Red Flowering Almond. (P. Japonica flore rubro pleno.) 3 to $4 \mathrm{ft}$. May. A charming, low growing shrub which in its season is covered with double pink or red flowers.

\section{PURPLE FRINGE}

Purple Fringe or Smoke Tree. (R. continus.)

True Purple Fringe. (var. atropurpurea.) A form with flowers of a deep reddish purple. 


\section{SIBERIAN PEA TREE-Caragana}

C. arborescens. 10 to $15 \mathrm{ft}$. June. By some this is cataloged under deciduous trees but in the North and West it belongs among tall growing shrubs.

\section{SPIREA-Meadow Sweet}

Ash-Leaved Spirea. (sorbifolia.) $5 \mathrm{ft}$. July.

Billard's Spirea. (S. Billardi.) $4 \mathrm{ft}$. July and Aug. A strong grower with dull green foliage and dense panicles of bright pink flowers.

Fortune's Spirea. (S. callosa.) 3 to $4 \mathrm{ft}$. June.

Fortune's Dwarf White Spirea. (var. alba.) $2 \mathrm{ft}$. Blooms all summer.

Golden Spirea or Golden-Leaved Nine Bark. (opulifolia var. aurea.)

Lanced-Leaved Spirea. (S. Reevesii.) June.

Thunberg's Spirea. (S.Thunbergii.) 3 to $4 \mathrm{ft}$. May.

Van Houtte's Spirea. (S. Van Houttei.) 4 to $5 \mathrm{ft}$. June. Perhaps the most poplar of all the Spireas and has been the most planted. It is of upright tho pendulous growth with foliage of rich green which assumes pleasing autumnal coloring. When covered with its dense clusters of pure white flowers, the branches are weighted down nearly to the ground.

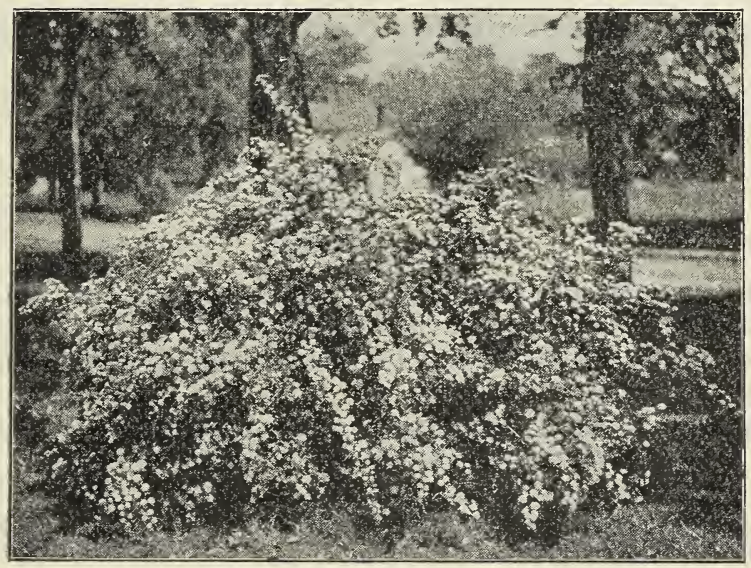

Spirea

Willow-Leaved Spirea. (S. salicifolia.) $4 \mathrm{ft}$. July and August.

S. Douglassi. $3 \mathrm{ft}$. August. Deep Rose.

S. Bumalda. 2 to $3 \mathrm{ft}$. July and August. (var. Anthony Waterer.) Dwarf. Crimson.

S. arguta. $3 \mathrm{ft}$. May. Japan. 


\section{SIBERIAN HEDGEWOOD}

The best low growing, hardy hedge yet discovered. It was introduced several years ago by Prof. N. E Hanson, of S. D. We have tested it upon our grounds for several years and believe it will take its place as a standard hedge shrub in this section. It stands shearing without injury, and is very attractive. It is hardy clear to the tips and one of the most favorable features is that the buds start early. The hedge is green and handsome fully two weeks before other hedge shrubs are in leaf. Foliage hangs on late in the fall.

\section{SNOWBALL}

Common Snowball or Guelder Rose. (var. sterillis.) 6 to $8 \mathrm{ft}$.

Japanese Snowball. (V. plicatum.) 4 ft. May. SNOWBERRY

Snowberry. (Symphoricarpus racemosus.) $4 \mathrm{ft}$. July and August.

\section{SUMACH-Rhus}

Smooth Sumach. (R. glabra.) 8 ft. June. Handsome, pinnate foliage, assuming splendid autumn coloring. Showing spikes of crimson fruits.

Cut-Leaved Sumach. (var. laciniata.) A variety of the above with deeply-cut, fern-like foliage.

Staghorn sumach. (R. typhina.) 8 to 12 ft. A. showy, broad headed shrub.

\section{SYRINGA OR MOCK ORANGE}

\section{Philadelphus}

Golden Mock Orange. (var. aureus.) 3 to $5 \mathrm{ft}$. A compact shrub with bright yellow foliage.

(var. speciosissimus.) Of graceful habit with branches. bending slightly at the tips.

Gordon's Mock Orange. (P. Gordonianus.) 8 to $12 \mathrm{ft}$. July. One of the strongest growers, with very large, pure white flowars.

Large-Flowered Mock Orange. (P. grandiflorus.) 8 to $12 \mathrm{ft}$. June.

Sweet Mock Orange. (P. coronarius.) 8 to $12 \mathrm{ft}$. June. The old and well known Mock Orange. In June completely covered with showy pure white flowers of a delightful fragrance.

\section{VIBURNUM}

Arrow Wood. (V. dentatum.) $6 \mathrm{ft}$. June. 


\section{Climbing and Trailing Shrubs or Vines}

We list below the best and hardiest varieties in this class, such as by experience has been found most satisfactory in the northern states.

Approximate blossoming season is represented by the months given in the description of those varieties, prominent for their flowers.

\section{BITTERSWEET - Celastrus}

climbing Bittersweet, Faise Bittersweet. (C. scandens.)

\section{CLEMATIS--Virgin's Bower}

C. carulea. Delicate lilac.

Henryi. A robust plant and a free bloomer. Flowers creamy white. Large flowered varieties.

Jackmani. Flowers are large, intense violet purple. Remarkable for its velvety richness. It is a free grower and an abundant bloomer.

Madam Edward Andre. Flowers a beautiful, bright, velvety red.

C. paniculata. July and September. It is a very rapid climber, and desirable wherever a strong and rapid growing vine is needed, on walls, verandas, fences, etc. In late summer it produces dense sheets of medium sized, pure white flowers.

C. Vitacella. This is one of the oldest and best types of the Clematis.

c. Virginiana: (Virgin's Bower, American White Clematis.) August. It is a native of the Northwest and succeeds everywhere.

\section{CHINESE MATRIMONY VINE-Lycium}

L. Chinese. May.

\section{HONEYSUCKLE-Lonicera}

Hall's Evergreen Honeysuckle. (var. Halleana.)

Trumpet Honeysuckle. (L. sempervirens.) One of the best climbers of the class, scarlet or orange scarlet.

SOLANUM-Nightshade

German Bittersweet. (S. dulcamara.)

WOODBINE-Ampelopsis

Virginia Creeper or Common Woodbine. (A. quinquefolia.)

Engelman's Woodbine. (var. Engelmanii.) 


\section{Herbaceous Perennial Plants}

\section{List of Selected Varieties Suitable for Lawn Planting in the Northwestern States}

No ornamertal lawn planting. what ever its extent. can be complete without a liberal proportion of these hardy flowering plants. The ease with which they are maintained is an important factor, but their great and varied scope of usefulness gives them still greater importance. Not only do they enter into selection they at the same time yield a profusion of bloom for indoor decoration thru six months of the year. In height they range from six to eight or more feet thus offering proper gradation for mass groups and wide selection for specific purposes.

\section{ASTER-Starwort}

New England Aster. Purple flowers with yellow center.

\section{ARTEMESIA - Wormwood}

Silky Wormwood. (A. frigida.) $1 \mathrm{ft}$. September. One of the most beautiful of the genus, with very finely-cut foliage. Will thrive in poorest of soil.

\section{BLEEDING HEART, DIELYTRA--Dicentra}

Bleeding Heart or Seal Flower. (D. spectabilis.) 3 ft. June. Long racemes of showy, heart-shaped, red and white flowers. By far the handsomest of its tribe, and will grow both in shady or sunny locations, but blooms more freely when given plenty of sun.

\section{BOLTONIA--False Chamomile}

A class much resembling the Asters, yet giving a far different effect. Of easy culture and a fine addition to the autumn list.

B. astorides. 3 fi. September. Pure white flowers.

BUTTERCUP_Ranunculus

Bachelor's Button. Has golden yellow flowers.

COREOPSIS-Tick Seed

C. grandiflora. $3 \mathrm{ft}$. June-October. America. Large, deep yellow, cup-shaped flowers.

\section{COLUMBINE-Aquilegia}

Golden Spurred Columbine. (A. Ch rysantha.)

Rocky Mt. Columbine. (A. cærulea.)

\section{DAY LILY-Hemerocallis}

These are exellent plants with grass-like foliage and dar $\mathrm{k}$ orange colored flowers borne in panicles on long stems. They are exceptionally hardy, thriving in any good soil and are especially adapted to moist and shady places.

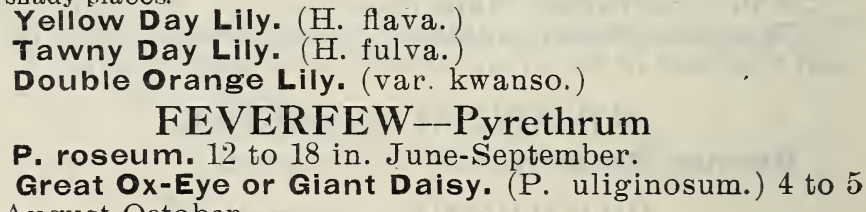
ft. August-October.

\section{FORGET-ME-NOT-Myosotis}

This well known genus of plants scarcely needs description. They thrive in moist. half shady places and will also grow to good advantage in the border. 


\section{FOX-Glove-Digitalis}

A small and showy genus of perennial plants of easy culture. They prefer a rich, loamy soil and partial shade. Certain species are used in medicine.

Common Fox-Glove, Fairy Fingers or Witch's Fingers. (D. purpurea.) 4 to $5 \mathrm{ft}$. July.

\section{GAILLARDIA-Blanket Flower}

G. aristata var. grandiflora. $1 \mathrm{ft}$. June-September.

\section{GOLDEN GLOW-Rudbeckia}

Golden Glow. (R. laciniata) $6 \mathrm{ft}$. July-September, Very large, double dahlia-like flowers of a brilliant, golden yellow color.

\section{HOLLYHOCK - Althea}

Indispensable plants in the garden or border, possessing a character peculiar to themselves which renders them especially valuable to break up any set effect in lawn planting Can furnish the most desirable colors in both single and double forms.

\section{IRIS-Rainrow Flower, Fleur de Lis}

The flowers are borne on long stems which bring them well up above their own foliage and that of other plants when grown in borders and beds.

The tuberous Iris are divided into several classes as follows.

\section{IRIS-Japan}

Apple Blossom. White spoted with pink.

Commodore Perry. Large; blue. Petals yellow at base.

Emperor. Large handsome purple.

Gold Bound. Pure white; base of petals golden yellow.

Mahogany. Dark red, shaded maroon.

Mt. Hood. Deep blue; of good form.

Pyramid. Violet purple, veined white.

Robt. Craig. French gray, tinted with purple on center petals.

Victor. Blue-white, veined with violet.

\section{IRIS-German}

Augustina. Deep yellow and maroon.

Fulda. Satiny white; luwer petals lilac, feathered yellow.

Florentina alba. Sweet scented. Early flowering, white.

Gazella. White, heavily frilled with rich mauve.

Humbolt. Nearly white.

Lord Salisbury. Standards amber and white; falls dark purple with white veinings.

Madam Chereau. White, fringed with azure blue.

Mrs. Newbronner. Very deep golden yellow, and one of the best yellows.

Pallida. Light indigo blue. Very large.

Parisiensis. Large, showy; deep purple.

Pearl. Large white; very handsome.

Stenophylla. Blue and white.

Silver King. Flowers silvery white. Distinct and fine.

Velvetine. Standards, pale amber color, falls creamy white, veined with mauve.

\section{LOBELIA-Cardinal Flower}

L. Cardinalis. $2 \mathrm{ft}$. September. America. The flowers of this variety are of an intense bright scarlet and are one of the showiest of all our native flowers. 


\section{LILY OF THE VALLEY - Convallaria}

c. majalls. 6 in. May-June. The Lily of the Valley is too well known to need description. Its spikes of pure white flowers and charming fragrance have made it a fav. orite for many centuries.

\section{PEONY-Peonia}

Peonies succeed admirably in any loamy soil and may be made to thrive in the shady parts of the lawn where other flowering plants refuse to bloom. For bordering walks and driveways and for the flower garden. an assortment of Peonies is quite indispensible. Ourlist includes some of the choicest varieties that have been tested on our grounds. By making proper selection, the blooming period may be extended in many locations from the middle of May to the end of June. They offer a range of color from pure white to deep purple. and many of them are fragrant.

\section{Peonia chinensis-chinese Peony Double Varieties}

Note: The nomenclature of the Peony is in a more or less chaotic state owing to the vast number of seedlings and hybrids brought out in the past few years. Our list comprises the cream of the hundreds of varieties we have tested in our trial gardens. The very finest colors and largest blooms are among them. A longer list would only make a selection confussing to the buyer.

Artemise. A fine rose pink. Double row of outside petals. Strong grower; free bloomer. A very solid color.

Canarie. White, yellow center.

Delachil. Purplish crimson, shaded violet.

Dorchester. Late free bloomer. Delicate salmon flesh color; excellent, for all purposes.

Delicatissima. A shade darker than Artemise. Outside petals blend in with the pompon. Strong grower; free bloomer. Another fine pink.

Duc de Wellington. Single row of outside petals flesh. color. Center, narrow petal straw color. Outside ones of these being same as outer petals. Fades to pure white. Strong grower; profuse bloomer, every. shoot bearing a flower. One of the best white.

Felix Crousse. Brilliant red.

Festiva Maxima. Large, very double; pure white. Center petals fringed with red. Long stems.

Fulgida. Crimson.

Grandiflora rubra. Large, blood red.

J. Discaisne. Very similiar to Jean d'Arc.

Jerome. Pink.

Jean d'Arc. Flower in three sections. Single row of outside petals flesh pink, slightly darker than Madam Courant. Next, very double section of fringed narrow straw colored petals. Inside of this a raised center of almost white petals, these being large, with crimped edges. A distinct flower.

L'Esperance. Sweet-scented rose.

Modeste. Deep rose, bright, showy, fragrant.

Madam Courant. Center very double, creamy white; center petals red.

Purpurea Superba. Almost identical with Prince de Talindyke. 
Prince de Talindyke. Dark red; very double.

Queen Victoria. Outside blush, white flesh center. Rubra. Common red Peony

Rubra Suporba. Rich purplish crimson.

Rubra Triumphans. Rich purplish crimson. Single White. White.

Triumph du Nord. Solid color of rose pink.

\section{POPPY - Papaver}

Oriental Poppy. (P. orientale.) 2 ft. June. Has large thistle-like leaves about a foot long, clothed with white bristly hairs. Its deep orange scarlet flowers have a dark purple spot at the base of each petal. They are of exceptional size, frequently measuring six inches across.

\section{PHLOX-Hardy Perennial Varieties}

Ground or Moss Pink. (P. subulata.) 4 in. May. Rose colored flowers. As a cover plant and for rockery work, we know of nothing that excels this. The foliage, handsome and moss-like, makes a close carpet of green and when in flower the plant forms a sheet of color.

\section{Hybrid Phlox}

P. paniculata and P. maculata. These hybrid varieties range in height from two to four feet. With these varieties the flowers are borne in large, showy heads and in nearly every case on good stiff stems for cutting. red eye.

Aglæ Adamson. Immense flowers snow white with

Albion. White with pink eye.

Bridesmaid. Pure white, with crimson eye.

Champignot. Bright rose color.

Champs Elysee. Purplish crimson.

Coquelicot. Orange scarlet, carmine eye.

Esias Tegner. Deep rose.

Eugene Danzenvillier. Lilac, with white edge and center.

E. G. Von Lassburg. Purest white in cultivation. Flowers larger than any other white.

Gen. Von Hentz. Scarlet, with rose shadings and crimson red eye.

Geo. A. Strohlein. Bright scarlet, with crimson red eye.

La Feu de Monde. Bright salmon red; late.

Lanibore. Bright rose.

Le Mahdi. Deep reddish violet, with darker eye.

Mad. Paul Deutrie. Delicate lilac rose; large flowers.

Madam Meuret. Flame color, carmine center.

Madam Pape Carpentier. Pure white; early dwarf.

Michæl Buchner. Dark purple.

Miss Lingard. Pure white; lavender eye. Early.

Moliere. Salmon rose, with deeper eye.

Mrs. Jenkins. Pure white; very fine.

Pantheon. Deep salmon rose.

Professor Schlieman. Bright lilac rose; carmine eye.

R. B. Struthers. Bright pink salmon.

Sceleton. White, with red eye.

Siebold. An improved scarlet variety. 
Stanislaus. Bluish in color.

Von Hochberg. Ideal crimson Phlox. Rich color.

William Robinson. Pale salmon; rose center.

\section{SHASTA DAISY - Chrysanthemum}

Shasta Daisy. (C. Leucanthemum hybridum.) Originated by Mr. Luther Burbank of "California. The flowers are very large; color white with golden center. They are bold in effect; profusely borne on good stems for cutting.

\section{SWEET WILLIAM, HARDY PINK}

Sweet William. (D. barbatus.) 18 in. June-July. Germany. An old flower garden favorite. It sports into endless varieties of color-white, pink, purple, crimson, scarlet, and many sorts variously edged, eyed or spotted.

\section{YUCCA-Adam's Needle}

Y. filamentosa. 4 to $5 \mathrm{ft}$. June-July. The best known species of Yucca and best adapted to the Northwest. Has stiff, broad, sword like foliage and surmounted by tall handsome spikes of large, fragrant creamy white flowers. Valuable in producing sub-tropical effect and a group of them upon the lawn commands instant attention when the monstrous heads of flowers are open.

\section{Field or Out Door Roses}

We have long made a specialty of growing rose plants and carry a most complete stock of our own growing, the largest of any nursery in the North. The plants we offer are all two year old field grown. The following lis comprises only a small number of those we propagate.

We have restricted this list to the very bes $t$ and most vigorous varieties that are especially suited to the extreme North.

For convenience. the varitties are alphabetically arranged irrespective of the class to which they belong. Each variety is keved as follows; C. Climbing; H, P. Hybrid Perpetual; J. June; M. Moss; H. R. Hybrid Rugosi.

The Hybrid Perpetuals are the best varieties where a wealth of bloom in rose garden is desired. For hedge work or lawn grouping. the Rugosas and June roses are best adapted. The Moss and Brier roses are desirable for a number of purposes. All varieties marked "C" are the best sorts for porches. trellises and places where a climbing rose is needed.

Varieties appearing in heavy type are best "all around" varieties. Anne de Diesbach. H. P. In color the most lovely shade of carmine.

Baby Rambler. C.

Baltimore Belle. C. Pale blush.

Baron de Bonstetten. H. P. Dark Red

Baron Prevost. H. P. Pure rose color; very large, full.

Black Prince. H. P.

Blanch Moreau. M. Pure white.

Capt. Hayward. H. P. Red.

Clio. H. P. Flowers large, flesh color. One of the best.

Conrad F. Meyer. H. R. Large, elegantly formed buds and flowers, $3 \frac{1}{2}$ to 4 inches across and perfectly double; color, silvery pink. Very fragant. Entirely hardy and desirable in every way.

Comtesse de Murinais. M. One of the best pure white Moss Roses; flowers large, fragrant; good bloomer. 
Countess de Roseberry. H. P. Pink.

Dorothy Perkins. C. hardy climbing rose, shell pink.

Fisher Holmes. H. P. May be briefly described as an improved General Jacqueminot.

Francois Levet. H. P. An unsuaily strong and vigorous grower, and very free bloomer. Large, round stately flowers; color, bright rosy carmine. Fragrant; beautiful.

Frau Karl Druschki. H.P. A pure paper-white, free flowering, large sized Hybrid Perpetual.

Gem of Prairie. C. Rose-red.

General Washington. H. P. Red shaded with crimson.

General Jacqueminot. H. P. A strong, vigorous grower, entirely hardy; an early aud abundant bloomer. Both buds and flowers are considered models of perfection, and its brilliant shining crimson is the standard of color by which other roses are judged.

Glory de Margottin. H. P. Red.

Hansa. H. R. Deep pink very double. Absolutely hardy and requires no winter protection.

Harrison's Yellow. J. Clear golden yellow.

John Hopper. H. P. Bright rose with carmine center.

Jubilee. H. P. Dark Red. Very fine.

Hugh Dickson. H. P. Vigorous grower; bright crimson, shaded scarlet.

La Reine. H. P. Deep pink flowers, large and fragrant; hardy and productive.

Mad. George Bruant. H. R. Flowers large size, semidouble, Color pure glistening white.

Mad. Masson. H. P. Blooms nearly all the time, red.

Magna Charta. H. P. Extra large, very double; rosy red, beautifully flushed with violet crimson; sure bloomer.

Margaret Dickson. H.P. Large, handsome white rose.

Madam Plantier. J. One of the hardy June white rose.

Marchioness of Lorne. H. P. Rose; shaded carmine.

Multiflora. C. A creamy white double.

Memorial. C. (Wich). Single whitebrightgolden center.

Moss Crested. M. Deep pink colored buds, surrounded with a mossy fringe and crest; free from mildew. A fragrant and very beautiful rose.

Paul Neyron. H. P. Deep rose color.

Prince Camille de Rohan. H. P. Velvety crimson.

Prairie Queen. C. Clear bright pink.

Princess Adelaide. M. Pale rose.

Red Moss. Large, full, deep crimson.

Rugosa Rubra. Japanese variety. Flowers single, of most beautiful bright rosy crimson.

Rambler Crimson. C. Flowers are a bright, cheerful shade of crimson.

Seven Sisters. C. Blush, tinged with various shades.

Uirich Brunner. H. P. Brilliant cherry red.

\section{Bulbs and Tubers}

Dahlias, Gladiolus and Tulips, in all the leading colors and varieties. 


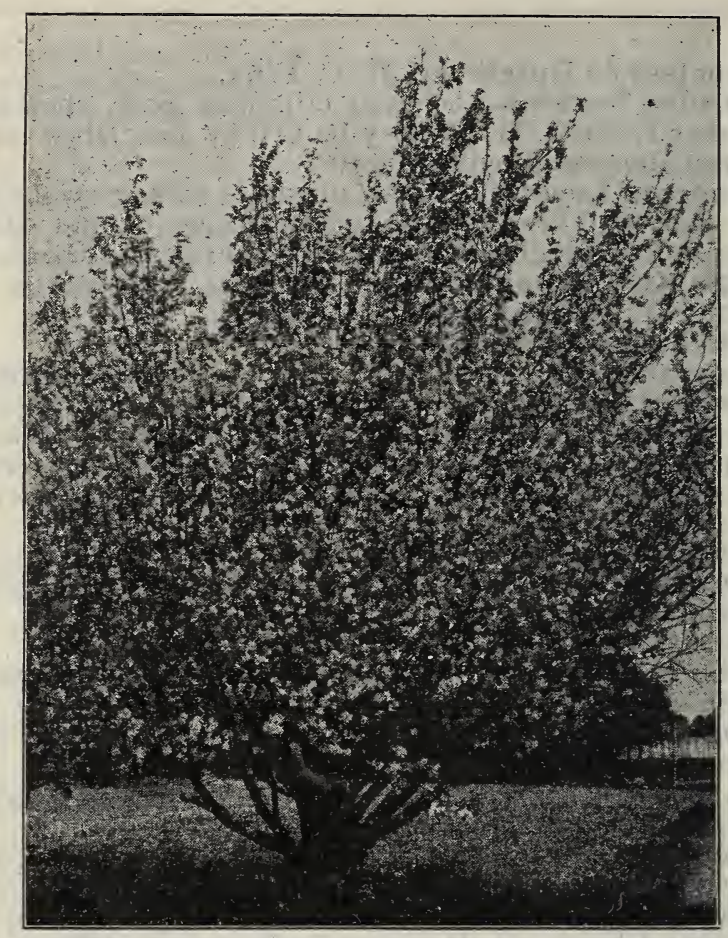

Wealthy Apple Tree in Bloom

\section{INDEX}

Page

Page

Apples ......... 3-6

Asparagus........ 19

Blackberry ........ 18

Bulbs and Tubers.. 39

Cherries .......... 12

Compass Cherry .. 11

Crabs........... 6-7

Currants ........12-14

Dewberries ....... 18

Evergreens .......24-26

Gooseberries ......14-15

Grapes ........15-16

Herb. Per. Plants. 34-38

Horse Radish .... 18

Juneberry ....... 18

Plums .......... 8 $8-10$

Raspberries...... 16-17

Rhubarb........ 19

-Roses.......... 38-39

Shelter-Belt Stock 26

Shrubs......... 27-32

Strawberries..... 19

Trees........... 20-24

Vines........... 33 